\title{
Analysis of the Status of Women Directors: A Study on the Listed Financial Institutions of Bangladesh
}

\author{
Chowdhury Saima Ferdous ${ }^{1} \&$ Habiba Rahman ${ }^{2}$ \\ ${ }^{1} \mathrm{PhD}$, Professor, Department of International Business, University of Dhaka, Dhaka, Bangladesh \\ ${ }^{2}$ Research Assistant, Department of International Business, University of Dhaka, Dhaka, Bangladesh \\ Correspondence: Chowdhury Saima Ferdous, Phd, Professor, Department of International Business, University of \\ Dhaka, Dhaka, Bangladesh.
}

Received: March 11, 2019

Accepted: March 22, 2019

Online Published: March 25, 2019

doi:10.5539/ibr.v12n4p130

URL: https://doi.org/10.5539/ibr.v12n4p130

\begin{abstract}
This paper investigates the status of women directors of Bangladesh using all the listed financial institutions of this country. Particularly, the paper considers three issues: the number of women working as directors, their qualification; and their recruitment process. Using a mixed method, the overall findings of the study reveals a very dissatisfactory status of the women in the top position in the Financial Institutions of Bangladesh. It also indicated that, though the number of qualified women is increasing but the rate of growth is slow like many other countries. The patriarchal society and the socio-cultural factors are still dominating the recruitment process of women as a director. Though the overall findings show a sluggish growth of the status of women at the top position, the findings of this study indicate the gap in understanding of the policy makers and also among women, which will help in developing effective policies for ensuring gender diversity at the board level.
\end{abstract}

Keywords: women directors, financial institutions, nomination, leadership

\section{Introduction}

\subsection{Introduction}

The increasing number of research on gender diversity at the board level certainly indicates its importance in ensuring good governance. However, the literature review suggests that both developed and developing countries are still struggling to ensure a satisfactory result on gender diversity at the board level. Whilst, board diversity is considered as an integral part of competitive decision making process, a significant number of studies (e.g. Reguera-Alvarado et. al., 2017; Conyon and He, 2017; Moreno-Gómez et. al., 2017; Sharma, 2014; Francoeur et. al., 2008) strongly emphasized on gender diversity to be very specific. For instance, Mallin (2004) stated that "in most of the cases the diversity is defined broadly in terms of gender or nationality"; and another group of studies (e.g. Aribi et. al., 2018; Gallego and Gutierrez, 2018; Lee et. al., 2017; Terjesen et. al., 2015; Dezső and Ross, 2012) stated with empirical evidences that gender diversity is crucial for companies to attain competitive advantage.

For example, Terjesen et. al. (2015) found that female directors enhance firm's performance. With the help of Tobin's Q method, they found that the presence of women on at board is positively correlated with firm performance. Similarly, Dezső and Ross (2012) identified that, firms with women portrayal can attain high-rank performance since their empirical result is significant. They think that firms should incorporate women at the board level because board with women can achieve better performance than board without women; as women are perceived by the shareholders to be more ethical than men.

However, one of the major reasons behind the sluggish growth of gender diversity at the board level around the world might be lies with the mixed evidences of the impact of gender diversity on board performance. For instance, some studies (e.g. Chen et. al., 2016; Pletzer et. al., 2015; Hili and Affes, 2012; Adams and Ferreira, 2009) found gender, as in, women in the board or leadership role is insignificant for companies' success. A very recent research of Lukviarman and Johan (2018) reviewed the literature of past 15 years, and found that women on board have a negative impact on firm performance. Unfortunately, similar result echoed in some other studies, like Zeng, (2018) and Bokhari and Hashmi (2016). Zeng (2018) found in his empirical study based in China that, there is no notable impact of gender diversity on performance because the characteristics of female directors 
have no impact on the level of the firm's performance. A similar result had been found in the qualitative study of Bokhari and Hashmi (2016) based on Asian countries. The scholars assumed that the conventional perception about women's capability as leader might have influenced behind this result. Whilst the above mentioned studies claim negative impact, some other studies (Fujianti, 2018; Williams, 2003; Harrigan, 1981) rather preferred to be inconclusive about the impact based on their findings. Because they found that women directors have less concentration on firm's economic needs than their male counterparts. And for this, outside women directors are more preferable in the big firms than inside directors. These empirical studies are based in both developed and developing countries which makes these results more acceptable. Although they can't exactly find any relationship between gender diversity and firm's performance because of their limitations, they emphasized the significance of women on the board of a company.

The findings of most of these studies are not generalizable for several reasons. For instance, the studies which indicated a negative impact of having women on board are limited on their sample size. For instance, the study of Fujianti (2018) used 40 companies as sample and indicated in their paper it as one of their limitations. Moreover, most of the literature is based on developed (e.g. Europe, US, Ireland, Kenya) countries. (e.g Mandala et. al., 2018; Owen and Temesvary, 2018; Ward and Forker, 2015; Cabo et. al., 2012). Since, each country differs with socio-cultural aspect which has significant influence over the decision making approach, the available findings cannot be generalized for all. The studies (e.g. Aribi et. al., 2018, Gallego and Gutierrez, 2018, Handley et. al., 2018; Hasan et. al., 2018; Cheng et. al., 2017; Dezső and Ross, 2012; Deloitte, 2011) which advocated for the presence of women at the board level, emphasized on the fact that to make a positive impact on firm performance, women need to meet up certain qualification like any other competent board leaders. For instance, Handa (2018) highlighted on the number of women, Solimene et. al. (2017) emphasized on the qualification and some demographic features, Some recent studies repetitively stated that having any woman is not only detrimental for the company, they might reestablish the old stigma on women that they are less competent as leaders compare to men. Hence, they also strongly opined that women's appointment on board should be based on fair criteria i.e. their merit and competence.

Having women at the top position is additionally challenging for many of the developing countries like Bangladesh, where traditionally, the society is nurturing the Patriarchal culture. Hence, it is good to see that the interest is increasing on the gender diversity issues in these kind of countries (e.g. Hasan et. al., 2018; Abobakr and Elgiziry, 2017; Shetu and Ferdous, 2017; Badrul et. al., 2015) ). One of the extensive studies on women directors is the study of Deloitte (2011). This study found that, the presence of women in the top position of the public firms of Asian countries is not more than $10 \%$ were in other countries (e.g. US, UK, EU, Canada, Australia) the women participation in the top position of the public firms is around $15 \%$ only. It is clearly visible that, the rate of participation of women is significantly low; even lower than developed countries. Bangladesh, as a case of study is interesting. Because, traditionally patriarchal system dominates the socio-cultural factors, and the corporate sector is dominated by family owned companies. These two combinations are certainly a big challenge for women to break the glass ceiling and aspire to leadership position. According to the World Bank (2018), the GDP Growth rate of Bangladesh will rise from 6.5\% to 7\% in the year 2019, for which ensuring a healthy private sector is considered as fundamental. At this point, not including women in the decision making process will be expensive for the country, as a good number of studies (like, Mandala et. al., 2018; Owen and Temesvary, 2018; Abobakr and Elgiziry, 2017; Ward and Forker, 2015; Cabo et. al., 2012) feared that exclusion of women from the decision making process means excluding half of the customers' mind, and excluding the potential of half of the population of a country. Realizing the necessity of gender diversity at different level of the economy, women empowerment has been considered as one of the important agendas by the Government of Bangladesh for almost a decade. These agendas have emphasized on women's right on education and facilitated their entrepreneurial skill. Several awareness programs took place against stereotypes, and participation of at least one (1) percent of women on at the board have been made mandatory by the corporate governance regulations of the Bangladesh Securities and Exchange Commission.

As a result, the official statistics (e.g. the Bangladesh Bureau of Statistics, UCEP Bangladesh and Diakonia Bangladesh, 2017) revealed that female students have outnumbered males in different academic fields, which naturally develops an expectation that a good number of women should be found in professional fields too. However, among the few studies on Bangladesh, one of the recent studies by Shetu and Ferdous (2017) identified that women in Bangladesh are struggling to take their career to the top; the typical barriers along with the most common one "family responsibilities" there are other obstacles (e.g. discrimination in promotion and payment, lack of role model, lack of determination among women to overcome the barriers in raising up career and so on) which have been found as the reasons behind the lack of women at the top position in the corporate 
sector of Bangladesh. The study also claimed that although the number of women increased at the entry level, but it starts decreasing sharply as the career-path leads to the top. The stereotypical ideas over gender diversity prevails in Asian countries, as have been claimed by a number of researchers (e.g. Lukviarman and Johan, 2018; Fujianti, 2018; Zeng, 2018; Bokhari and Hashmi, 2016). One recent study found that only a small number of women (23\% in top position, $15.1 \%$ in parliament and $12 \%$ in other areas), are holding the top position of the Bangladeshi corporate sector (Shetu and Ferdous, 2017). This percentage is not good enough to make a significant impact on firm performance. On top of, neither this study nor other studies on developing countries systematically analyzed the profiles of these women which is integral for any directors to make a positive impact on firm performance.

Overall, it is high time for any developing countries like Bangladesh which are aspiring to be middle income country, to consider every single potential it has to boost the economy of the country, and gender diversity is certainly one of those untapped potential which deserves much attention.

Based on the above justifications, this research aims to understand the status of women who are working at the leadership position in the listed financial institutions of Bangladesh. The main objectives of the study are,

1. To identify the number of the women directors of the listed financial institutions of Bangladesh,

2. To analyze the profile of the women directors of the listed financial institutions of Bangladesh, and

3. To analyze the recruitment process of the women directors of the listed financial institutions of Bangladesh.

This study contributes in two ways, theoretically and practically. Previous studies show the significance of gender diversity in corporate board. The participation of women directors is slowly increasing and they have a strong profile in other countries' financial institutions as well as the whole corporate sector. Although the boards of FIs of Bangladesh have included women might be due to the listing regulations, the number in proportion to the board size has not been studied systematically. Moreover, to make a positive impact on firm performance, regardless of the gender Directors must have a certain amount of qualification and experience, thus their recruitment basis needs to be scrutinized before making any conclusion on the competence of women are serving as board members. This study will fill this gap in understanding taking the case of Bangladesh as a developing c.

Furthermore, after the series serious of home grown corporate scandals (for instance, stock market failure in 1996 and 2011, Sonali bank - Hallmark loan scandal, Oriental Bank, Bismillah Group; Janata Bank and Bangladesh Bank - the Central Bank of Bangladesh) corporate governance regulators of the countries are showing interest to make policies to ensure good governance. Admitting, the findings of Aribi et. al. (2018) and Gupta and Jain (2018), that the presence of women at board increases accountability and fairness, they have made policies as mandatory for all the banks to follow to have women at board. However, as have been discussed above if the right women are there who are not hired due to their competence and then the old stigma of women's competence will be reestablished. Hence, the findings of this study are expected to help policy makers to understand the gaps (if any) in their existing policy.

\subsection{Theoretical Background}

The New Institutional Sociology (NIS) theory provides the theoretical background for this study. NIS theory states that, to act properly, rationally and reliably, different organizations seek legitimacy so that they can act in a similar manner (Suchman, 1995; Jepperson, 1991; Parsons, 1960). DiMaggio and Powell, (1983; 1991,) explained that to adopt legitimacy, organizations must follow some common legal and regulatory laws which can change their structure. They further stated that, these laws may come from both government and other non-governmental bodies. According to Siddiqui (2010), the corporate governance scenario of Bangladesh is consistent with the propositions ${ }^{1}$ of the NIS theory. For example, the regulatory bodies' behaviors towards the companies regarding appointing women in top position match the NIS theory through the rational choice institutionalism and feminist institutionalism. Because, the rational choice institutionalism stated about the rational behavior of the regulatory bodies towards the firms and the feminist institutionalism talks about how gender and firm incorporate together (Nee, 2003; Brinton and Nee, 1999). To appreciate female in the workplace, positive view towards appointing female directors and family members had been shown in the laws of the important Bangladeshi corporate actors such as Bangladesh Securities and Exchange Commission (BSEC) guideline,. Since there is a law for appointing women as board members, the companies included women for

1 The main propositions of NIS theory are normative institutionalism, rational choice institutionalism, sociological institutionalism, historical institutionalism and feminist institutionalism (Nee, 2003; Brinton and Nee, 1999). 
compliance not for out of their believe on the importance of different opinion women bring to the board, or different leadership skills needed by the board. However, the desired qualifications of women for director position have not been mentioned in the policies. Moreover, the company act 1994 allows companies to include family members up to $55 \%$ of the ownership, but no specific mandatory requirements for the qualification of them. This creates the scope for companies to bring anybody to the board just for the sake of compliance. Hence, it is highly possible that the women who are working with the board have been invited for legitimacy where little priority has been given on their qualification. Hence, the NIS theoretical propositions are adopted in this study to understand the status of women and the perception of the respondents in addressing the research questions.

\subsection{The Status Women on Board of Different Countries}

To understand women directors' status, reviewing their number, profile and recruitment process is an important criterion. By this time a good number of studies have emerged identifying if the participation of women has increased in number and their impact on performance. For instance, in a study of Indonesia, Fujianti (2018) stated that qualified women add new dimension to the board decision and thus can add value to firms' performance. García-Meca et. al. (2014) studied multicounty \& stated that bank performances of 9 different countries (Canada, France, Germany, Italy, the Netherlands, Spain, Sweden, the UK and the US) have increased due to gender diversity on corporate board.

However, from the very beginning, the researchers advocating for gender diversity at the board level have been emphasizing on some prerequisites before taking the decision to include women at the board level as a mandatory option; and qualification and competence is certainly one of them. For instance, Burke (1993) and Burgess and Tharenou (2002) strongly stated that only, those women with good characteristics and better qualification, can enhance board as well as management performances; and they rejected the idea of having women as a 'token'.

Some studies (e.g. Solimene et. al., 2017; Horváth and Spirollari, 2012; Burgess and Tharenou, 2002) used age, education, experience, marital status, number of children and role on board as women directors' profile. These studies preferred comparatively young women (e.g. age around 40 years old) to be on the board, as they were found to be comparatively enthusiastic in taking risks and creating positive influences (Horvath and Spirollari, 2012; Salim, 2011; Kang et. al., 2007; Burgess and Tharenou, 2002). While reviewing the educational profile, studies like Singh et. al. (2008), Burgess and Tharenou (2002) and Hillman et. al. (2002) found that, female directors' hold higher degrees such as, masters and PHD degree compared to their male directors. And Soleimene et. al. (2017) \& Dang et.al (2014) did not measure the impact but they stated that higher education has the potential to lead a better experience for other members and expertise on board.

While marital status was found to be a significant variable for women to aspire to leadership position due to family responsibilities. It is almost common in every country that marital status and number of children adds more responsibility on women compared to their male partner. However, it was interesting to see the findings of Burgess and Tharenou, 2002, which is based on Australia, USA, Canada, UK, New Zealand and Israel. The study found that, at the board level, the number of married women and women with children is higher than women who are unmarried and do not have children. However, the findings are not surprising, as for women the age of getting married is abided by the social norm in many countries, mostly in South-Asian countries, and bearing children is abided biologically. Hence, the time when people get into the job, males can focus more on career and females need to balance the social and biological orders. This balancing takes time for to reach to the top and many gives up even before breaking the glass ceiling. Although female Chair and CEO generate benefits for companies, women in these positions are hardly found (Sahay et. al., 2017; Wang and Kelan, 2013; Linda, 2005).

Regardless of gender, the recruitment process of directors has also been studied by some studies. Like the study of Burgess and Tharenou (2000) found in general directors are appointed in their different ways such as, demographic, experiential, and organizational. Among this, the scholars preferred the demographic factor as it ensures board diversity in a meaningful way. When it comes to the question of women at top position, Some countries like Australia, France, Us and Canada preferred a quota system, as they said quota is the only way to break the stereo typed notion about women's competence scholars because previously women were not appointed on leadership position because of many qualified candidates, not realizing their importance, their unpredictable career and the negative view towards them (like Handley et. al., 2018; bdullah, 2014; Nekhili and Gatfaoui, 2013; Sweigart, 2012 Brammer et. al., 2007; Leonie, 2006; Bonn, 2004; Sheridan, 2001; Burke, 1997; Daily et. al., 1999; Panteli et. al., 1999; Elgard, 1983). However, these countries did not give any less emphasis on the level of competence of those women who deserved to be at the board. However, scholars like, Tatli et. al. 
(2012), Pande and Ford (2012) are completely against this quota system, as they argued that if companies are pressurized to have a women at board through quota system, for the sake of compliance wither they will fit anybody or not so right women for the position for the sale of compliance.

Bangladesh has laws on recruiting women directors too. However, they have been very recently in acted. The BSEC guideline 2012 \& 2018 stated that at least one board member should be female; and this is mandatory for all listed companies. A study by Siddiqui and Ferdous (2016) found that family business is in lead position in having women, and they stated the reason behind this is that the company act 1994 added the provision of including family members up to $55 \%$ of the ownership of companies. Furthermore, the bank company act (1991) of Bangladesh said that, "At the same time, no more than 4 [four] more members from any single family will be held in the position of the director of any banking company". This provision clearly means that there is a possibility of appointing family members in the director position. However the study revealed their fear of such pressure of legitimization of including women through quota, since in reality they found there is lack of competent women at the pipeline to be an effective board member. Unless a proper policy is implemented to encourage women leadership and raise a women to reach to the top, there is a chance of having women who will not be able to make significant or any or negative contribution to firm performance.

\section{Method}

\subsection{Identify Subsections}

This section is divided into two subsections. First subsection includes the description of respondents and participants and justification of their participations. Second and last subsection includes the sampling procedures and sample size and precision; measures and the research design.

\subsection{Participant Characteristics}

The participants of this research are both male and female individuals who are working in the board of directors of the sample companies given below. They are eligible for this research because the study is based on the women directors of sample companies' boards. For proper justification of the research, focus group interviews and personal interviews of both male and female respondents have been conducted.

\subsection{Sampling Procedures}

The target population of this study is all the financial institutions listed on the Dhaka Stock Exchange (DSE) at the end of 2017. The financial institutions have been divided into two major groups, banking institutions and non-banking financial institutions. During that period, total 100 financial institutions were listed on the DSE. The secondary source such as, annual reports of FY 2016-2017 of all financial institutions had been used to collect data. As the research is based on the secondary data, the responded are exactly the same number of the population size.

\subsubsection{Sample Size, Power, and Precision}

Table 1 describes the industry classes of the financial institutions of the DSE.

Table 1. Industry Classes of the Financial Institutions of the Dhaka Stock Exchange

\begin{tabular}{ccccccc}
\hline & Industry Classes & & \multicolumn{2}{c}{ Population } & \multicolumn{2}{c}{ Sample } \\
\cline { 3 - 6 } & & $\begin{array}{c}\text { Total Listed } \\
\text { Financial } \\
\text { Institutions in the } \\
\text { Industry }\end{array}$ & $\%$ Total & $\begin{array}{c}\text { Responding } \\
\text { Companies } \\
\text { (Sample) }\end{array}$ & Sample \\
\hline \multirow{2}{*}{$\begin{array}{c}\text { Financial } \\
\text { Institutions }\end{array}$} & $\begin{array}{c}\text { Banking } \\
\text { Institutions }\end{array}$ & Bank & 30 & $30 \%$ & 30 & $30 \%$ \\
\cline { 2 - 6 } & $\begin{array}{c}\text { Non-Banking } \\
\text { Financial } \\
\text { Institutions }\end{array}$ & Insurance & 47 & $47 \%$ & 47 & $47 \%$ \\
\cline { 2 - 6 } & Leasing & 23 & $23 \%$ & 23 & $23 \%$ \\
\hline
\end{tabular}

\subsubsection{Measures and Covariates}

The first research objective, is to identify the number of women directors, two types of data had been used which have been used in previous studies (Handa, 2018; Gupta and Jain, 2018; Cheng et. al., 2017; Deloitte, 2011; Neilsen and Huse, 2010). For this objective, the number and percentage of the board size, male and female directors had been identified. The second research objective, which is to analyze the profile of female directors, will be considered the data following the study of Sahay et. al., 2017; Solimene et. al., 2017; Singh et. al., 2008 and Burgess and Tharenou, 2002 (as have been discussed in pg 8). The profile includes into five (05) different variables such as, directors' age, education, marital status, experience and role on board. The director wise 
percentage, company wise percentage and age range of female directors had been identified. In order to understand the last research objective, that is to analyze the recruitment process of women directors, how they have been recruited, whether they are in family business or their profile matters had been used as data. The data for these objectives are quite similar to the data of various researches conducted previously (Handley et. al., 2018; Abdullah, 2014; Nekhili and Gatfaoui, 2013; Sweigart, 2012).

\subsubsection{Research Design}

This study is a mix of both qualitative and quantitative methods. All the objectives had been analyzed using both methods. Number, percentage, range had been used and an explanation of them had also been done. The findings were first categorized adopting thematic analysis. Later, the findings were converted to quantitative data using descriptive statistics for objective analysis.

\section{Results}

This section attempts to explain the status of the women directors of listed financial institutions of Bangladesh. The findings as well as the analysis of the three research objectives of the study have been included respectively. Table 2 compares the percentage of male and female directors' presence in the listed companies according to the board size.

Table 2. Percentage of the Women Directors in the Listed Financial Institution

\begin{tabular}{ccccccc}
\hline Sector & \multicolumn{2}{c}{ Board size } & \multicolumn{2}{c}{ Male } & \multicolumn{2}{c}{ Female } \\
\hline & Number & $\begin{array}{c}\text { Percentage } \\
(\%)\end{array}$ & Number & $\begin{array}{c}\text { Percentage } \\
(\%)\end{array}$ & $\begin{array}{c}\text { Number } \\
\text { Percentage } \\
(\%)\end{array}$ \\
\hline Bank & 417 & 100 & 375 & 90 & 42 & 10 \\
Insurance & 746 & 100 & 581 & 78 & 165 & 22 \\
Leasing & 254 & 100 & 220 & 85 & 34 & 15 \\
\hline Total & 1417 & 100 & 1176 & 83 & 241 & 17 \\
\hline
\end{tabular}

The table 2 shows the percentage of the women directors of the listed financial institutions. It appears that the ratio of male directors and female directors is 5:1 with the listed financial institution of Bangladesh. From the table, it is clear that the percentage of male directors in the total companies are $83 \%$ and that of women directors is only $17 \%$. These findings declare that, women participation rate is very low in the listed financial institutions. And that might even be due to the BSEC provision that requires the presence of at least one women on board (see Appendix A). According to the NIS theory, when compliance is done to conform with social rules, that often fails to realize the expected benefits of compliance. Hence, the women who existing even with the low ration, has the possibility of lacking required competence and act their fiduciary duties as a Director.

In order to understand the justification of this proposition, following the triangulation method, this study interviewed a few respondents, and requested to shed light on it. One of them (female) confidently said now women can be seen at boards due to compliance with legal provisions, and more are not there because of the social taboos, stereotyped mentalities about the competence of women. Some other respondents also highlighted on the discriminatory behavior women at the top are facing, and they preferred to blame the established culture which accepted women to be lower in all aspects compare to men.

However, an interesting fact emerged while analyzing the profiles of the women leaders at the board. Although the provisions ${ }^{2}$ do not specify anything about the qualifications of the Directors as have been explained in OECD principles (See Appendix B) all of the female directors were found to be highly educated (see table 2), and all of them were University graduates. The literature review section (in page 3) explained education background is important for all the directors regardless of gender to be effective in leadership roles. The study of Ferdous (2018) also expressed this concern by stating that over the last two decades among the university business graduated females are dominating the top position in the merit list. She also expected that these meritorious women have the potential to be a successful leader. But, to be successful in leadership positions the

${ }^{2}$ i. Company Act 1994: (1) Every public company and a private company which is a subsidiary of a public company shall have at least three directors; (2) Every private company other than a private company shall have at least two directors and (3) Only a natural person may be appointed a director.

ii. BSEC Corporate Governance Regulation (2018): board of directors shall be constituted of in proportionate to the shareholding of: (a) promoters or sponsors or shareholders who control over individually or persons in concert; and (b) general shareholders including institutional shareholders, excepting independent directors' quota; where general shareholders' portion (quota) may be filled up by at least one general shareholder, female director(s), independent director(s) and/or executive director(s). 
director must have knowledge, expertise and appropriate environment (Tricker, 2015; Mallin, 2013). Unfortunately, this study revealed that the women who are serving on the board, meet the educational qualification criteria, however, their nomination is influenced by kinship; not by their expertise. Thus, only education might not be helping them much to perform effectively.

This is not unique in Bangladesh. As Ferdous (2018) in her study also stated that in most of the countries where family owned companies dominate the corporate sector, Directors' nomination is to some extent obvious to be influenced by family members; and not all the men Directors take the leadership position through competence, they learn through experience, they are given the environment to grow up as Directors. Now the question arises, if women are also nominated in the same way, if they get the chance to grow. Unfortunately once again the social stereotypical notions come forward and the NIS proposition of the box compliance surfaced up as the findings of this study. In answering the question about the environment majority of the women claimed that "we are treated as a box ticking option, we are yet to get that acceptance like men that we will grow if we get the opportunity to work as a leader". Whilst some of the men respondents out rightly said, they have been taken as a token for compliance, and some other expressed their doubts over the competence of women. Hence, the discrimination in getting the right environment was very clear.

The table 3 presents the educational background of the women directors of the listed financial institutions of Bangladesh. From the table, it can be identified that all the women directors are university graduates but only $19 \%$ women directors of the total listed financial institutions have post graduate degree. This is quite similar to Australia (like, 28\% female directors have Masters Degree or PHD) and quite opposite to New Zealand (like, 83\% female directors have Masters degree or PHD) (Burgess and Tharenou, 2002). The believable ground of this situation is that, the women with good educational background have the basic knowledge of the works which makes them more skilled in their profession. One of the directors of leasing sector said that, "University graduates can understand the need of the firm easily and can work accordingly, however, Masters degree or PHD is for the academic sector."

Table 3. Educational Background of the Women Directors

\begin{tabular}{ccccc}
\hline Sector & \multicolumn{2}{c}{ Graduation } & \multicolumn{2}{c}{ Post-Graduation } \\
\cline { 2 - 5 } & Number & Percentage $(\%)$ & Number & Percentage $(\%)$ \\
\hline Bank & 42 & 18 & 17 & 7 \\
Insurance & 165 & 68 & 17 & 7 \\
Leasing & 34 & 14 & 12 & 5 \\
\hline Total & 241 & 100 & 46 & 19 \\
\hline
\end{tabular}

Table 4 indicates the age range of women directors in the listed financial institutions. It states that the average age of the women directors in the listed financial companies is 45 years. So it emerges that the group of young women is leading the listed FIs which make them more compatible to adopt new ideas of leadership and the mixing up with the corporate culture becomes easy for them. This finding is similar to the Australian corporate sector which has younger group (45-49) of female directors; but slightly differs with the United States which has the older group (50-59) of female directors (Burgess and Tharenou, 2002). It means the age existing women on board in Bangladesh are compatible enough to exert more if the rest of the qualification and environment are given.

Table 4. Age range of the Women Directors

\begin{tabular}{cl}
\hline Sector & Age range \\
\hline Bank & $30-50$ years \\
Insurance & $33-75$ years \\
Leasing & 31-63 years \\
\hline
\end{tabular}

Table 5 presents the number of different types of directorship held by women in the FIs of Bangladesh. The most important factors to notice in the table is that, i) none of the women directors are working as executive director, i.e. they are not an employee of the company and not responsible for monitoring over the implementation of the strategic plans; ii) most of the women directors (87\%) are non-executive directors. In answering "Why mostly non-executive?" both male and female respondent said, "Because it is easy to accommodate women as the non-executive director". This certainly raises concern about their intention of having women on board. Future studies should be carried on identifying the given roles and responsibilities of those female directors as non-executive directors. It wasn't possible for this study to explore the facts because the data was not available in secondary sources and the respondents also preferred to avoid answering this. According to Burgess and Tharenou (2000), also supported this concern by stating that it is easier because the social norms influence the firms to appoint women in non-executive position and women get less support from their families and counterparts. 
Table 5. Type of Directorship Held by Women

\begin{tabular}{cccccc}
\hline Sector & Chairperson & Vice Chairperson & $\begin{array}{c}\text { Executive } \\
\text { Director }\end{array}$ & $\begin{array}{c}\text { Non-Executive } \\
\text { Director }\end{array}$ & $\begin{array}{c}\text { Independent } \\
\text { Director }\end{array}$ \\
\hline Bank & 0 & 3 & 0 & 34 & 4 \\
Insurance & 2 & 9 & 0 & 148 & 7 \\
Leasing & 3 & 2 & 0 & 27 & 2 \\
\hline Total & 5 & 14 & 0 & 209 & 13 \\
\hline
\end{tabular}

However, it is good to see that, (see in Table 5) women have also been selected as independent director and Insurance companies are in the lead. Hence, if the expertise and environment is ensured, women have the potential to break the stereotypes and prove their competence as an independent director.

The following table 6 presents the marital status of the women directors of the listed financial institutions of Bangladesh. It states that $93 \%$ female directors of the listed financial institutions are married which does not match that of any other countries such as, Australia (have 65\%), US (have 69\%) and Canada (have 71\%) (Burgess and Tharenou, 2002). This massive amount of married women in the top position is not surprising in the Bangladeshi context since there is a trend of early marriage. Most of the females get married in their student life and so they have to work after marriage which as claimed by the respondents has significant negative impacts such as, not attending board meetings, early departure from the office and resigning after having children. In replying "what to do in this state?" one of the female respondents again drag the topic of the view of this society and said that, "As long as our attitude towards women does not change, they can't be able to lead beside men." This statement is similar to the study of Bokhari and Hashmi (2016) which declared that this continental has a backdated view towards women empowerment. This clarifies the fact that the social environment is not quite suitable for women even in this 21 st century.

Table 6. Marital Status of the Women Directors

\begin{tabular}{ccccc}
\hline Sector & \multicolumn{3}{c}{ Married } & Unmarried \\
\cline { 2 - 5 } & Number & Percentage $(\%)$ & 3 & Percentage $(\%)$ \\
\hline Bank & 38 & 16 & 2 & 3 \\
Insurance & 163 & 70 & 2 & 2 \\
Leasing & 33 & 14 & 7 & 7 \\
\hline Total & 234 & 93 & 7 & 2 \\
\hline
\end{tabular}

Finally, Table 7 shows the year range of women directors' experience of the listed financial institutions of Bangladesh. The average year of experience is 25 years which have been found by the following findings which indicates that women directors have somewhat moderate to high experience. The banking and leasing sectors have similar results but the interesting part is the result of the insurance sector. It indicates that the insurance sector appoints less experienced women which is not good for the board level job as stated by the respondents. One respondent from this sector mentioned that, "the intensive recruitment of family member in the board is the root cause for this less experienced members in the board." The family business becomes a trend now in this country. Most of the insurance companies have both male and female family members in the boards. The plausible reason (see more on page 17) for this as argued by a respondent is the easy recruitment process of family member on the board. And that leads to an inexperienced company board which has been headed towards the corruption.

Table 7. Year of Experience of the Women Directors

\begin{tabular}{cc}
\hline Sector & Year Range \\
\hline Bank & $15-31$ \\
Insurance & $8-35$ \\
Leasing & $15-37$ \\
\hline
\end{tabular}

Surprisingly, analyzing the recruitment process of the women directors reveals very rare findings. According to the table 7 , the highest percentage $(50 \%)$ of recruitment process is through the family. Unexpectedly, the companies don't recruit women directors through the existing policy (e.g. SEC Guidelines). The feasible cause of this situation is the laws (e.g. The Company Act, 1994 and The Bank Company Act, 1991) of including family members in the leadership position. Despite there is lots of qualified women working on the board, it is shocking that no one has been employed for their high-ranked profile. According to the feminist institutionalism of NIS theory, this situation declares that the firms don't have positive views towards appointing women in the leadership position. And this is very much unlikely with other countries where profile is the main factor to recruit on the board (Burgess and Tharenou, 2000). And so the chances of corruption and incompatible board remain high. 
Table 8. Recruitment Process of the Women Directors

\begin{tabular}{ccccccccc}
\hline Sector & \multicolumn{2}{c}{ Nomination } & \multicolumn{2}{c}{ Promotion } & \multicolumn{2}{c}{ Policies } & \multicolumn{2}{c}{ Family Business } \\
\hline & Number & $\begin{array}{c}\text { Percentage } \\
(\%)\end{array}$ & Number & $\begin{array}{c}\text { Percentage } \\
(\%)\end{array}$ & Number & $\begin{array}{c}\text { Percentage } \\
(\%)\end{array}$ & $\begin{array}{c}\text { Number } \\
\text { Percentage } \\
(\%)\end{array}$ \\
\hline Bank & 19 & 8 & 3 & 1 & 0 & 0 & 20 & 8 \\
Insurance & 65 & 27 & 11 & 5 & 0 & 0 & 90 & 38 \\
Leasing & 18 & 7 & 5 & 2 & 0 & 0 & 10 & 4 \\
\hline Total & 102 & 42 & 19 & 8 & 0 & 0 & 120 & 50 \\
\hline
\end{tabular}

The respondents from the interview stated some reasons of this situation of the recruitment process of women at the leadership position. They are: 1) lack of proper use of policies and guidelines; 2) easy appointment of family members; 3) discrimination in the family and the workplace; 4) lack of realization of women importance; 5) and lack of motivation and support from others. The reasons make it easier to state that the corporate sector of this country has been ruled by family business which creates a massive threat for the accountability and transparency of companies. Although women have high profile and there is a policy regarding hiring women as directors, it seems that there is no use of it. Hence, tokenism has been already developed in the companies. And so, this unhealthy condition can bring massive disasters like the stock market failure in 1996 and 2011, Sonali bank Hallmark loan scandal, Oriental Bank, Bismillah Group; Janata Bank and Bangladesh Bank - the Central Bank of Bangladesh.

The aim of this section is to provide a discussion about the findings and analysis of the three research objectives which are to analyze the number, profile and recruitment process of women directors of the listed financial institutions. It demonstrates that, the listed financial companies have a low rate of women directors but they have a very good profile background. Most of them were recruited through family business because of backdated views towards women.

\section{Discussion}

Overall, it appears that, the scenario of Bangladesh regarding the percentage of women working at the top is not unique, rather resembles with the existing literatures: only a small number of women are working in the leadership position of the listed financial institution, and the most plausible reason is the necessity of confirming to the legislation. However, the profile of the women working at the top position is quite satisfactory in terms of age \& educational background. Nonetheless, their independence is at stake, because of their percentage in comparison with the counterpart. Moreover, to make a remarkable contribution as director age and education is not enough, rather as the studies (Bokhari and Hashmi, 2016; Burgess and Tharenou, 2000) said, leadership style, working environment and competence is also crucial; thus the recruitment policy or system should have been appropriate. This study showed that women have been appointed as Chairperson, Vice Chairman, non-executive and independent director; and these roles are crucial and demands experience along with visionary skills. However, due to nepotism and compliance reasons with mandatory provisions companies are hiring women, not for their competence rather for conformance. Overall, it appears that the scenario of the women in the top position is nothing different than countries around the world, but the ways many developed countries have taken measures to encourage more competent women to be at the top to ensure gender diversity Bangladesh has limited itself only within ineffective laws, which has made it worse by making it mandatory.

Future studies should concentrate on the recommendations to overcome such problems, specifically the recommendations which are customized according to the reality of the corporate sector which is not supported by strong legal and regulatory framework and dominated by family owned companies and where the patriarchal stereotypical mentality prevails. Future studies should be carried on non-listed companies of Bangladesh and also on the successful women leaders who broke the glass ceiling and ensure their position with their own right.

\section{Acknowledgments}

Cordeally thanks to the peer reviewers, editors, associate editors, and consulting editors of International Business Research. Both the authors contributed equally to the study. Thanks to Chowdhury Saima Ferdous for her personal assistance in manuscript preparation and Habiba Rahman for her personal assistant in data collection.

\section{References}

Abdullah, S. N. (2014). The Causes of Gender Diversity in Malaysian Large Firms. Journal of Management and Governance, 18, 1137. https://doi.org/10.1007/s10997-013-9279-0

Abobakr, M. G., \& Elgiziry, K. (2017). The Relationship Between Board of Directors' Characteristics and Bank Risk-Taking: Evidence from Egyptian Banking Sector. Journal of Finance and Accounting, 5(1), 24-33. https://doi.org/10.11648/j.jfa.20170501.13 
Adams et. al. (2004). Gender Diversity in the Boardroom. Working Paper N. 58/2004. available at: http://ssrn.com/abstract=594506

Adams, R. B., \& Ferreira, D. (2009). Women in the boardroom and their impact on governance and performance. Journal of Financial Economics, 94, 291-309. https://doi.org/10.1016/j.jfineco.2008.10.007

Andaleeb S. S., \& Wolford G. V. (2004).Participation in the workplace: gender perspectives from Bangladesh. Women in Management Review, 19(1), 52-64. https://doi.org/10.1108/09649420410518430

Anne, S. (2012). Women on Board for Change: The Norway Model of Boardroom Quotas As a Tool For Progress in the United States and Canada. 32 Nw.J. Int'lL. \& Bus.81A. available at: http://scholarlycommons.law.northwestern.edu/njilb/vol32/iss4/6

Bangladesh Bureau of Statistics, UCEP Bangladesh, Diakonia Bangladesh. (2017). Education Scenario in Bangladesh: Gender perspective, 1-51.

Bank Company Law. (1991). Ministry of Law, Justice and Parliamentary Affaires, Bangladesh.

BEI. (2004). Code of Corporate Governance for Bangladesh. Bangladesh Enterprise Institute.

Bell, L. A. (2005). Women-led firms and the gender gap in top executive jobs. IZA Discussion Papers, No. 1689, Institute for the Study of Labor (IZA), Bonn.

Bianco et. al. (2015). Women on Corporate Boards in Italy: The Role of Family Connections. Corporate Governance: An International Review, 23(2), 129-144. https://doi.org/10.1111/corg.12097

Bokhari, S. N., \& Hashmi, K. A. (2016). A Critical Review on the Corporate Governance, Board Independence and Gender Diversity in Emerging Asian Countries. Journal of Culture, Society and Development, 25.

Bonn, I. (2004). Board Structure and Firm Performance: Evidence from Australia. Journal of the Australian and New Zealand Academy of Management, 10(1), 14-24. https://doi.org/10.1017/S1833367200004582

Brammer et. al. (2007). Gender and Ethnic Diversity Among UK Corporate Boards. Journal Compilation, 15(2), 393-403. https://doi.org/10.1111/j.1467-8683.2007.00569.x

Brinton, M. C., \& Nee, V. (1999). The New Institutionalism Sociology. Contemporary Sociology, 28. https://doi.org/10.2307/2655306

Burgess, Z. M. \& Tharenou, P. (2000). What Distinguishes Women Nonexecutive Directors from Executive Directors?", In: Burke R.J., Mattis M.C. (eds) Women on Corporate Boards of Directors, Issues in Business Ethics, 14. https://doi.org/10.1007/978-90-481-3401-4_8

Burgess, Z. M., \& Tharenou, P. (2002). Women Board Directors: Characteristics of the Few. Journal of Business Ethics, 37, 39-49. https://doi.org/10.1023/A:1014726001155

Burke, R. J. (1997). Women Directors: Selection, Acceptance and Benefits of Board Membership. Corporate Governance: An International Review, 5, 118-125. https://doi.org/10.1111/1467-8683.00052

Burke, R. J. (1997). Women on Corporate Boards of Directors: A Needed Resource. Journal of Business Ethics, 16(9), 909-915. https://doi.org/10.1023/A:1017987220508

Cabo et. al. (2012). Gender Diversity on European Banks' Boards. Journal of Business Ethics, 109(2), 145-162. https://doi.org/10.1007/s10551-011-1112-6

Chen, G. C., \& Huang, S. Z. (2016). Female Board Representation and Corporate Acquisition Intensity. Strategic Management Journal, 37(2), 303-313. https://doi.org/10.1002/smj.2323

Cheng, Y. et. al.. (2017). When Do Racial and Gender Diversity Pay? Florida State University.

Company Act. (1994). Ministry of Law, Justice and Parliamentary Affaires, Bangladesh.

Conyon, M. J., \& He, L. (2017). Firm performance and boardroom gender diversity: A quantile regression approach. Journal of Business Research, 79, 198-211 https://doi.org/10.1016/j.jbusres.2017.02.006

Daily et. al.. (1999). A Decade of Corporate Women: Some Progress in the Boardroom, None in the Executive Suite. Strategic Management Journal, 20, 93-99. https://doi.org/10.1002/(SICI)1097-0266(199901)20:1<93::AID-SMJ18>3.0.CO;2-7

Dang et. al.. (2014). Women on French Corporate Board of Directors: How Do They Differ from Their Male Counterparts? The Journal of Applied Business Research, 30(2), 489-508. https://doi.org/10.19030/jabr.v30i2.8420 
Deloitte. (2011). Women in the Boardroom: A Global Perspective. 1-28. available at: www.global.corpgov.deloitte.com

DiMaggio, P. J., \& Powell W. W. (1983). The Iron Cage Revisited: Institutional Isomorphism and Collective Rationality in Organizational Fields. American Sociological Review, 48, 147-160. https://doi.org/10.2307/2095101

DiMaggio, P. J., \& Powell W. W. (1991). Introduction', in W. W. Powell and P. J. DiMaggio (eds.), The New Institutionalism in Organizational Analysis (University of Chicago Press, Chicago), 1-40.

Elgart, L. D. (1983). Women on Fortune 500 Board. California Management Review, 25(4). https://doi.org/10.2307/41165036

Ferdous, C. S. (2018). Corporate Governance in Bangladesh: Evidence of Compliance. International Business Research, 11(3). https://doi.org/10.5539/ibr.v11n3p88

Fujianti, L. (2018). Top Management Characteristics and Company Performance: An Empirical Analysis on Public Companies Listed in the Indonesian Stock Exchange. European Research Studies Journal, 21(2), 62-76.

Gallego, J. M., \& Gutierrez, L. H. (2018). An Integrated Analysis of the Impact of Gender Diversity on Innovation and Productivity in Manufacturing Firms. IDB Working Paper Series No IDB-WP-865 Inter-American Development Bank, Institutions for Development Sector.

García-Meca, E. et. al. (2014) Board diversity and its effects on bank performance: An international analysis. Journal of Banking \& Finance.

Gupta, H., \& Jain, A. (2018). Disclosure of corporate governance practices in Indian life insurance companies. International Journal of Academic Research and Development, 3(2), 1478-1481.

Handa, R. (2018). Does Corporate Governance Affect Financial Performance: A Study of Select Indian Banks. Asian Economic and Financial Review, 8(4), 478-486. https://doi.org/10.18488/journal.aefr.2018.84.478.486

Handley, k. et. al.. (2018). The Same or Different: How Women Have Become Included in Corporate Leadership in Australia. In: Adapa S., Sheridan A. (eds) Inclusive Leadership. Palgrave Studies in Leadership and Followership, Palgrave Macmillan, Cham, https://doi.org/10.1007/978-3-319-60666-8_5

Hasan, T. et. al.. (2018). Role of governance on performance of microfinance institutions in Bangladesh. Eurasia Business and Economics Society, https://doi.org/10.1007/s40822-018-0102-8

Hili, W., \& Affes, H. (2012). Corporate Boards Gender Diversity and Earnings Persistence: The Case of French Listed Firms. Global Journal of Management and Business Research, 12(22).

Hillman, et. al.. (2002). Women and Racial Minorities in the Boardroom: How Do Directors Differ? Journal of Management, 28(6), 747-763. https://doi.org/10.1177/014920630202800603

Horváth, R., \& Spirollari, P. (2012). Do the Board of Directors' Characteristics Influence Firm's Performance? The U.S. Evidence, Prague Economic Papers, 4, 470-486. https://doi.org/10.18267/j.pep.435

Jepperson, R. L. (1991). Institutions, Institutional Effects, and Institutionalism. In W. W. Powell and P. J. DiMaggio (eds.), The New Institutionalism in Organizational Analysis (University of Chicago Press, Chicago), 143-163.

Kang, H. et. al., (2007). Corporate Governance and Board Composition: diversity and independence of Australian boards. Corporate Governance An International Review, 15(2), 194-207. https://doi.org/10.1111/j.1467-8683.2007.00554.x

Lee, H. W. et. al.. (2017) Does gender diversity help teams constructively manage status conflict? An evolutionary perspective of status conflict, team psychological safety, and team creativity. Organizational Behavior and Human Decision Processes, 187-199. https://doi.org/10.1016/j.obhdp.2017.09.005

Leonie V. S. (2006). Where are the women in leadership in Australia? Women in Management Review, 21(3), 180-194. https://doi.org/10.1108/09649420610657371

Lukviarman, N., \& Johan, A. P. (2018). Meta-analysis of corporate governance in Asia. Investment Management and Financial Innovations, 15(2).

Mallin, C. A. (2004). Corporate Governance (4th ed.). Oxford; New York: Oxford University Press. 
Mallin, C. A. (2016). Corporate Governance (5th ed.). Oxford; New York: Oxford University Press.

Mandala, N. et. al. (2018). An Empirical Investigation of the Relationship between Board Structure and Performance of Financial Institutions in Kenya. Journal of Finance and Investment Analysis, 7(1).

Moreno-Gómez, J. et. al. (2018). Gender diversity in the board, women's leadership and business performance. Gender in Management: An International Journal, 33(2), 104-122. https://doi.org/10.1108/GM-05-2017-0058

Muttakin, M. B. et. al. (2015). Firm characteristics, board diversity and corporate social responsibility. Pacific Accounting Review, 27(3), 353-372. https://doi.org/10.1108/PAR-01-2013-0007

Nee, V. (2003). New Institutionalism, Economic and Sociological. forthcoming, Handbook for Economic Sociology.

Nekhili, M. \& Gatfaoui, H. (2013). Are Demographic Attributes and Firm Characteristics Drivers of Gender Diversity? Investigating Women's Positions on French Boards of Directors. Journal of Business Ethics, 118, 227-249. https://doi.org/10.1007/s10551-012-1576-z

Owen, A. L., \& Temesvary, J. (2018). The Performance Effects of Gender Diversity on Bank Boards. Journal of Banking and Finance. https://doi.org/10.1016/j.jbankfin.2018.02.015

Pande, R., \& Ford, D. (2012). Gender Quotas and Female Leadership. Washington, DC: World Bank, World Bank. https://openknowledge.worldbank.org/handle/10986/9120

Panteli, et. al. (1999). Gender and Professional Ethics in the IT Industry. Journal of Business Ethics, 22, 51-61. https://doi.org/10.1023/A:1006156102624

Parsons, T. (1960). Structure and Process in Modern Societies (Free Press of Glencoe, New York).

Pletzer, J. L. et. al. (2015). Does Gender Matter? Female Representation on Corporate Boards and Firm Financial Performance-A Meta-Analysis. PLOS ONE https://doi.org/10(6):e0130005

Reguera-Alvarado, N. et. al., (2017). Does Board Gender Diversity Influence Financial Performance? Evidence from Spain. Journal of Business Ethics. https://doi.org/10.1007/s10551-015-2735-9

Sahay et. al. (2017). Banking on Women Leaders: A Case for More? IMF Working Paper, WP/17/199

Salim, D. (2011). Board diversity and firm performance: the Indonesian evidence. Corporate Ownership and Control, 8, 1-39.

SEC Guidelines. (2006). Bangladesh Securities and Exchange Commission.

SEC Guidelines. (2012) .Bangladesh Securities and Exchange Commission.

SEC Guidelines. (2018). Bangladesh Securities and Exchange Commission.

Sharma, S. (2014). Gender Diversity on Corporate Boards - A Study of NSE Listed Companies. International Journal of Applied Research and Studies (iJARS), 3(2).

Sheridan, A. (2001). A view from the top: women on the boards of public companies. Corporate Governance: The international journal of business in society, 1(1), 8-15. https://doi.org/10.1108/EUM0000000005456

Sheridan, A. (2001). A view from the top: Women on the boards of public companies. Corporate Governance: The International Journal of Effective board Performance, 1(1), 8-15.

Shetu, J. F., \& Ferdous, C. S. (2017). Glass Ceiling for Professional Women: A Study on Bangladesh. World Journal of Social Sciences, 7(2). 78-87.

Siddiqui, J. (2010). Development of Corporate Governance Regulations: The Case of an Emerging Economy. Journal of Business Ethics, 91, 253-274. https://doi.org/10.1007/s10551-009-0082-4

Siddiqui, J., \& Ferdous, C. S. (2016). The Regulatory Conundrum: Achieving Corporate Governance Reforms in Developing Countries. Corporate Governance in Emerging Markets: Theories, Practices and Cases. https://doi.org/10.1007/978-3-642-44955-0_18

Singh et. al. (2008). Female presence on corporate boards: a multicountry study of environmental context. Journal of Business Ethics, 83(1), 55-63. https://doi.org/10.1007/s10551-007-9656-1

Solimene, S. et. al. (2017). Gender Diversity on Corporate Boards: An Empirical Investigation of Italian Listed Companies. Palgrave Communications, 3. http://dx.doi.org/10.1057/palcomms.2016.109

Suchman, M. C. (1995). Managing Legitimacy: Strategic and Institutional Approaches. Academy of Management 
Review, 20(3), 571-610. https://doi.org/10.5465/amr.1995.9508080331

Tatli, A. et. al. (2012). An unrequited affinity between talent shortages and untapped female potential: The relevance of gender quotas for talent management in high growth potential economies of the Asia Pacific region. International Business Review.

Terjesen, S. et. al. (2015). Does the presence of independent and female directors impact firm performance? A multi-country study of board diversity. J Manag Gov. https://doi.org/10.1007/s10997-014-9307-8

Tricker, R. I. B. (2015). Corporate Governance Principles, Policies, and Practices (3rd ed.). Oxford University Press.

Wang, M., \& Kelan, E. (2013). The gender quota and female leadership: Effects of the Norwegian gender quota on board chairs and CEOs. Journal of Business Ethics, 17(3), 449-466. https://doi.org/10.1007/s10551-012-1546-5

Ward, A. M., \& Forker, J. (2015). Financial Management Effectiveness and Board Gender Diversity in Member-Governed, Community Financial Institutions. Journal of Business Ethics. https://doi.org/10.1007/s10551-015-2699-9

World Bank. (2018). GDP Growth, Annual. https://data.worldbank.org/indicator/NY.GDP.MKTP.KD.ZG?locations=BD

Zainal et. al. (2013). Corporate Board Diversity in Malaysia: A Longitudinal Analysis of Gender and Nationality Diversity. International Journal of Academic Research in Accounting, Finance and Management Sciences, 3(1), 136-148.

Zakaria A. A. et. al. (2018). Gender diversity on Boards and Forward-looking Information Disclosure: Evidence from Jordan. Journal of Accounting in Emerging Economies. https://doi.org/10.1108/JAEE-05-2016-0039

Zeng, C.Y. (2018). Independent Directors, Female Directors and Performance of Financial Listed Companies in China. Modern Economy, 9, 652-663. https://doi.org/10.4236/me.2018.94042

\section{Appendix A \\ BSEC Guideline}

At least 1 (one) member of the board of directors shall be a female who shall be qualified as a shareholder director or an executive director or an independent director.

\section{Appendix B}

\section{OECD Principles: Ensuring a formal and transparent board nomination and election process}

These Principles promote an active role for shareholders in the nomination and election of board members. The board has an essential role to play in ensuring that this and other aspects of the nominations and election process are respected. First, while actual procedures for nomination may differ among countries, the board or a nomination committee has a special responsibility to make sure that established procedures are transparent and respected. Second, the board has a key role in defining the general or individual profile of board members that the company may need at any given time, considering the appropriate knowledge, competencies and expertise to complement the existing skills of the board. Third, the board or nomination committee has the responsibility to identify potential candidates to meet desired profiles and propose them to shareholders, and/or consider those candidates advanced by shareholders with the right to make nominations. There are increasing calls for open search processes extending to a broad range of people.

\section{Copyrights}

Copyright for this article is retained by the author(s), with first publication rights granted to the journal.

This is an open-access article distributed under the terms and conditions of the Creative Commons Attribution license (http://creativecommons.org/licenses/by/4.0/). 